\title{
Erratum to: An Integrated Grammar- Pragmatics Approach: Teaching Style Shifting in Japanese
}

\section{Sayoko Yamashita and Noriko Ishihara}

\section{Erratum to:}

Chapter 8 in: A.G. Benati, S. Yamashita (eds.), Theory, Research and Pedagogy in Learning and Teaching Japanese Grammar, (C) The Editor(s) (if applicable) and The Author(s) 2016, DOI 10.1057/978-1-137-49892-2_8

The original version of this article was inadvertently published with an incorrect author group. The correct author group is given below:

Sayoko Yamashita and Noriko Ishihara

The updated original online version for this chapter can be found at DOI 10.1057/978-1-137-49892-2_8

(C) The Editor(s) (if applicable) and The Author(s) 2016 